\title{
Interaksi Sosial Anak Tunarungu dalam Sekolah Umum di TK Syafina Sidotopo Wetan Surabaya
}

\author{
Isnainia Solicha \\ Islam Negeri Sunan Kalijaga Yogyakarta \\ Email: isnainias.is@gmail.com
}

\begin{tabular}{|c|c|}
\hline Kata Kunci: & Abstrak \\
\hline $\begin{array}{l}\text { Interaksi } \\
\text { sosial, anak, } \\
\text { tunarungu, } \\
\text { tunawicara }\end{array}$ & $\begin{array}{l}\text { Anak tunarungu adalah anak yang kehilangan kemampuan dalam pendengaran. } \\
\text { Kehilangan kemampuan ini apabila terjadi sejak dini akan secara tidak langsung juga } \\
\text { mempengaruhi kemampuan berbicaranya. Sedangkan interaksi sosial sangatlah } \\
\text { memerlukan komunikasi di dalamnya. Apabila anak tunarungu kehilangan kemampuan } \\
\text { untuk berkomunikasi pasti akan kehilangan juga kesempatan untuk berinteraksi dengan } \\
\text { lingkungan di sekitarnya. Salah satu sekolah umum di daerah penulis yaitu, TK Syafina } \\
\text { menerima anak berkebutuhan khusus, yaitu anak tunarungu. Tidak adanya guru } \\
\text { pebimbing khusus yang disediakan oleh sekolah sangat menghambat anak tunarungu } \\
\text { dalam kegiatan belajar. Dalam penelitian ini menggunakan kualitatif deskriptif. Fokus } \\
\text { penulis yaitu, perilaku anak tunarungu di kelas, interaksi sosial anak tunarungu dengan } \\
\text { teman sebayanya, guru kelas, dan guru pendamping kelas. Berdasarkan hasil penelitian } \\
\text { yang dilakukan penulis dapat ditarik kesimpulan bentuk perilaku anak tunarungu di } \\
\text { kelas menyendiri, pendiam, mudah marah, dan mandiri. Interaksi sosial dengan guru } \\
\text { kelas dan guru pendamping kelas terjadi interaksi yang cukup baik, namun terkadang } \\
\text { guru kelas dan guru pendamping kelas kurang memahami maksud perkataan anak. } \\
\text { Interaksi sosial anak tunarungu dengan anak normal lainnya terjadi cukup baik dengan } \\
\text { ditunjukkan mereka saling berbagi, namun terkadang anak tunarungu lebih memilih } \\
\text { menyendiri daripada bermain bersama dengan anak normal. }\end{array}$ \\
\hline Keywords: & Abstract \\
\hline $\begin{array}{l}\text { Social } \\
\text { interaction, } \\
\text { children, deaf, } \\
\text { speech } \\
\text { impaired }\end{array}$ & $\begin{array}{l}\text { Deaf children are children who have lost their ability to hear. Loss of this ability if it } \\
\text { occurs early will also indirectly affect the ability to speak. Whereas social interaction } \\
\text { really requires communication in it. If the deaf child loses the ability to communicate, } \\
\text { he will also lose the opportunity to interact with the surrounding environment. One of } \\
\text { the public schools in the writer's area is, Syafina Kindergarten accepts children with } \\
\text { special needs, namely deaf children. The absence of special mentor teachers provided } \\
\text { by schools severely inhibits deaf children from learning activities. In this study using } \\
\text { qualitative descriptive. The author's focus is on the behavior of deaf children in class, } \\
\text { social interaction of deaf children with their peers, class teachers, and class teacher. } \\
\text { Based on the results of research conducted by the author, it can be concluded the form } \\
\text { of deaf child behavior in the class of solitude, quiet, irritable, and independent. Social } \\
\text { interaction with the class teacher and the class teacher occur quite well, but sometimes } \\
\text { the class teacher and class teacher do not understand the meaning of the child's words. } \\
\text { The social interaction of deaf children with other normal children occurs quite well by } \\
\text { showing them sharing, but sometimes deaf children prefer to be alone rather than } \\
\text { playing together with normal children. }\end{array}$ \\
\hline
\end{tabular}

Submission: October 17, 2019. Revised: November 23, 2019. Accepted: December 12, 2019

\section{A. Pendahuluan}

Interaksi sosial menurut $\mathrm{H}$. Bonner merupakan hubungan antara dua individu atau lebih, yang mana setiap perilaku satu individu di antaranya dapat mempengaruhi, mengubah, dan memperbaki perilaku individu yang lainnya (Ahmadi Abu, 2002). Poin yang dapat di ambil dari 
pendapat $\mathrm{H}$. Bonner adalah adanya suatu hubungan atau keterkaitan dan melibatkan minimal dua individu. Hubungan di antara dua individu ini dapat di mulai saat individu tersebut bertemu satu sama lain. Di dalam sekolah, peserta didik dapat membuat suatu hubungan berupa interaksi sosial terhadap guru, peserta didik, tenaga kependidikan, dan wali murid. Interaksi ini dapat terjadi di luar maupun di dalam kelas. Di luar kelas interaksi sosial yang dapat terjadi misalnya saat anak bermain dengan teman - temannya di ayunan bersama, berkomunikasi dengan orang tua anak lain, bahkan membeli makanan di kantin sekolah. Sedangkan interaksi sosial yang terjadi di dalam kelas saat adanya proses kegiatan belajar mengajar berlangsung.

Interaksi sosial tidak hanya terbentuk pada sekolah umum saja yang mana peserta didiknya tidak memiliki kebutuhan khusus yang menghambat belajar anak. Sekolah - sekolah di Indonesia juga menyediakan sekolah untuk peserta didik yang memiliki kebutuhan khusus, yaitu sekolah luar biasa dan sekolah inklusi. Sekolah luar biasa yaitu sekolah yang menampung peserta didik dengan berkebutuhan khusus bermacam - macam dan akan di tangani oleh guru yang ahli dalam bidangnya. Pendidikan inklusi pada umumnya sama dengan pendidikan umum. Namun, dalam pendidikan inklusi dapat menampung anak berkebutuhan khusus yang memiliki kemampuan dan bakat yang berbeda dari anak - anak lainnya mendapatkan pendidikan yang sama dengan anak normal pada umumnya. Pada kasus anak penyandang autis, kemampuan interaksi sosial adalah masalah utama yang mereka alami sehingga berdampak sistemik terhadap gangguan-gangguan lainnya (Fitriyah dan Mustofa, 2019).

Dalam pernyataan Salamanca (1994) dan Kerangka Aksi Dakar (1997) menyatakan bahwa pendidikan inklusif berusaha menangani kebutuhan belajar bagi seluruh anak, maupun orang dewasa yang memiliki kebutuhan khusus pada mereka yang rentan terhadap marjinalisasi dan diskriminasi (M. Takdir Ilahi, 2013). Pendidikan inklusif bertujuan untuk menyadarkan anak berkebutuhan khusus untuk memperjuangkan hak - hak mereka agar tidak termarginalkan dari masyarakat dan menghapus pelabelan negatif yang sering di berikan masyarakat pada anak berkebutuhan khusus. Jadi, dapat diartikan bahwa anak merkebutuhan khusus adalah seorang anak yang membutuhkan pendidikan khusus yang disesuaikan dengan hambatan belajar dan kebutuhan masing - masing anak secara individual (Zainal Alimin, 2016).

Anak dengan berkebutuhan khusus memiliki kategori yang bermacam - macam. Terdapat anak berkebutuhan khusus berupa tunanetra, tunawicara, autis, hiperaktif, cacat berupa fisik, tunarungu, dan berbagai macam lainnya. Anak tunarungu adalah seseorang yang mengalami kekurangan atau kehilangan kemampuan mendengar baik sebagian atau seluruhnya yang diakibatkan karena tidak berfungsinya sebagian atau seluruh alat pendengaran, sehingga ia tidak dapat menggunakan alat pendengarannya dalam kehidupan sehari-hari yang membawa dampak terhadap kehidupannya secara kompleks (Somantri Sutjihati, 2006).

Anak tunarungu adalah anak yang kehilangan kemampuan dalam pendengaran. Kehilangan kemampuan ini apabila terjadi sejak dini akan secara tidak langsung juga mempengaruhi kemampuan berbicaranya. Sedangkan interaksi sosial sangatlah memerlukan komunikasi di dalamnya (Somantri Sutjihati, 2006). Apabila anak tunarungu kehilangan kemampuan untuk berkomunikasi pasti akan kehilangan juga kesempatan untuk berinteraksi dengan lingkungan di sekitarnya. Mereka akan mengalami hambatan dalam mengembangkan kemampuan berbahasa dan penyesuaian sosial. Gangguan dalam pendengaran akan berdampak pula dengan kemampuan berbahasanya sehingga menghambat anak tunarungu untuk berinteraksi sosial (Sadjaah Edja, 2005). Dalam sosial masyarakat kemampuan berkomukasi verbal/lisan sangatlah di butuhkan. Sedangkan, bagi anak tunarungu kemampuan berkomunikasi akan sangat sulit untuk di lakukan. Sehingga dengan kata lain anak dengan 
gangguang pendengaran sebagai akibat dari pendengarannya, akan menghambat potensi dalam berkembangnya kemampuan berbahasa / berbicara anak (Sardjono, 2005).

Pentingnya interaksi sosial bagi anak tunarungu sangatlah berpengaruh bagi perkembangan sosial anak tunarungu. Berdasarkan beberapa observasi di salah satu lembaga Taman Kanak-kanak (TK) yang penulis temukan terdapat anak berkebutuhan khusus dengan keterbatasannya yaitu, tunarungu disertai dengan tunawicara. TK Syafina Surabaya merupakan TK islam umum yang terdaftar di Kementrian Pendidikan dan Kebudayaan kota Surabaya. TK ini didirikan sejak tahun 2012 sampai sekarang. Tidak adanya pendamping khusus yang di sediakan oleh TK Syafina sangat menghambat anak tunarungu dalam proses kegiatan pembelajaran. Model pembelajaran yang sering di pakai oleh guru kelas adalah model pembelajaran ceramah sehingga sedikit sulit untuk di terima oleh anak tunarungu. Anak tunarungu ini bernama Pi. Dalam berinteraksi dengan teman lainnya Pi cenderung menyendiri dan kurang berbaur dengan teman - teman lainnya. Pi juga cenderung masing bersifat manja dan tergantung pada orang lain.

Berdasarkan permasalahan diatas dapat diidentifikasi beberapa masalah yakni 1) tidak adanya guru pembimbing khusus bagi anak berkebutuhan khusus, 2) perlu adanya metode dan model pembelajaran yang dilakukan guru untuk membantu interaksi sosial anak tunarungu tersebut, 3) sikap dan perilaku anak tunarungu yang kurang nyaman berada di kelas, 4) kurangnya perhatian guru terhadap anak tunarungu, 5) sikap anak tunarungu yang mudah marah. Berdasarkan masalah tersebut peneliti ingin melihat interaksi sosial anak tunarungu secara intens dengan merumuskan beberapa masalah yakni a) bagaimana bentuk perilaku anak tunarungu selama sekolah, dan b) bagaimana interaksi sosial anak tunarungu dengan teman sebayanya, guru kelas, dan guru pendamping kelasnya.

Penelitian ini ingin berfokus mengobservasi perilaku anak tunarungu dan interaksi sosialnya dengan teman sebaya, guru kelas, dan guru pendamping kelasnya. Melalui penelitian ini diharapkan peneliti selanjutnya dapat memberikan solusi dan menjadikan penelitian ini sebagai rujukan referensi terhadap interaksi sosial anak tunarungu. Selain itu diharaplan penelitian ini dijadikan sebagai acuan bagi setiap guru untuk menghadapi dan menangani anak tunarungu agar dapat berinteraksi sosial dengan orang lain.

\section{B. Metodologi}

Penelitian ini merupakan penelitian kualitatif deskriptif jika digolongkan berdasarkan tujuannya. Penelitian ini akan berisi kutipan-kutipan data yang akan menggambarkan kondisi di lapangan (Lexy J. Moloeng, 2007). Penelitian bermaksud untuk mencermati interaksi sosial anak tunarungu di dalam sekolah umum, yaitu TK Syafina Sidotopo Wetan Surabaya secara mendalam.

Objek dari penelitian ini adalah interaksi anak tunarungu di TK Syafina Sidotopo Wetan Surabaya. Interaksi sosial ini dapat berupa interaksi sosial anak tunarungu dengan teman, guru kelas, dan guru pendamping kelas. Selain interaksi sosial anak tunarungu, peneliti juga mengamati bentuk perilaku anak tunarungu selama di dalam kelas. Dalam penelitian ini objek penelitian yaitu anak tunarungu akan diberi nama "Pi" sebagai nama samaran.

Dalam penelitian kualitatif, teknik pengumpulan data sebagai berikut: 1) observasi yang digunakan adalah observasi partisipasi pasif. Jadi, peneliti datang di tempat kegiatan orang yang di amati, namun tidak ikut terlibat dalam kegiatan tersebut. Teknik ini digunakan oleh peneliti untuk mengamati interaksi sosial anak tunarungu dalam pembelajaran dan kegiatan lainnya. Pedoman observasi yang digunakan dalam penelitian ini digunakan dalam kegiatan belajar di 
dalam kelas dan kegiatan di luar jam belajar. Subjek yang di observasi, meliputi anak tunarungu, guru kelas, guru pendamping kelas, dan anak normal. Sedangkan komponen yang diamati, meliputi cara berkomunikasi, kontak sosial, hambatan, dan proses interaksi sosial, 2) wawancara yang digunakan dalam penelitian ini adalah wawancara semi terstruktur. Wawancara semi terstruktur termasuk kategori in-dept interview, di mana pelaksanaannya lebih bebas. Teknik ini digunakan peneliti untuk mengungkap interaksi sosial anak tunarungu dengan berbagai sumber di lapangan. Beberapa komponen dalam pedoman wawancara, meliputi interaksi sosial anak tunarungu dengan subjek lain di sekolah, upaya guru dalam membantu interaksi sosial anak tunarungu dengan anak normal, upaya guru pendamping kelas dalam membantu interaksi sosial anak tunarungu dengan anak normal dan kontak sosial anak normal dengan anak tunarungu, 3) dokumentasi merupakan data yang mendukung untuk penelitian ini yang berfungsi untuk melengkapi data observasi dan wawancara. Dokumen ini dapat berupa tulisan, gambar - gambar, atau karya - karya yang berhubungan dengan interaksi sosial anak tunarungu di sekolah umum, yaitu TK Syafina Sidotopo Wetan Surabaya.

Analisis data adalah proses mencari dan menyusun data secara sistematis data yang diperoleh dari hasil wawancara, catatan lapangan, dan bahan - bahan lain, sehingga dapat mudah dipahami dan temuannya dapat diinformasikan kepada orang lain (Bogdan dalam Sugiyono, 2009). Aktivitas dalam analisis data model Miles dan Huberman adalah sebagai berikut: 1) reduksi data merupakan merangkum, memfokuskan pada hal-hal yang penting, memilih hal-hal yang pokok, dicari tema dan polanya. Reduksi data dilakukan secara terusmenerus dengan menghilangkan data yang tidak relevan dengan tujuan penelitian, dan menyimpan data yang di perlukan dalam penelitian ini. Adapun topik-topik yang akan dibahas dalam penelitian ini adalah interaksi sosial anak tunarungu di sekolah dan upaya guru dalam meningkatkan kemampuan interaksi sosial anak tunarungu, 2) penyajian data disajikan dalam bentuk uraian singkat, bagan hubungan antar kategori, flowchart, dan sejenisnya. Naum dalam penelitian kualitatif biasanya data disajikan dalam bentuk teks yang bersifat naratif. Adapun penyajian data dalam penelitian ini cenderung berupa teks yang bersifat naratif.

Instrumen utama dalam penelitian kualitatif adalah peneliti sendiri, namun memerlukan fokus penelitian yang jelas agar dapat mengembangkan instrumen penelitian untuk menunjang proses pengambilan data (Sugiyono, 2009). Dalam proses pengumpulan data, peneliti memerlukan alat bantu sebagai berikut.

1. Pedoman observasi ini digunakan peneliti untuk memfokuskan penelitian agar tidak menyimpang dari tujuan observasi. Observasi dilakukan saat proses pembelajaran dan saat di luar pembelajaran. Berikut adalah kisi-kisi observasi yang digunakan peneliti.

Tabel 1. Kisi-Kisi Pedoman Observasi

\begin{tabular}{|c|c|c|c|}
\hline No. & $\begin{array}{c}\text { Subjek } \\
\text { Observasi }\end{array}$ & Komponen & Indikator \\
\hline \multirow[t]{3}{*}{1.} & \multirow[t]{3}{*}{$\begin{array}{l}\text { Anak } \\
\text { Tunarungu }\end{array}$} & Komunikasi & $\begin{array}{l}\text { - Kecenderungan anak tunarungu dalam menggunakan } \\
\text { bahasa berkomunikasi. }\end{array}$ \\
\hline & & $\begin{array}{l}\text { Proses Interaksi } \\
\text { Sosial }\end{array}$ & $\begin{array}{l}\text { - Anak tunarungu melakukan proses asosiatif, yaitu } \\
\text { hubungan positif yang terjalin saat interaksi terjadi. } \\
\text { Seperti kerja sama dan kerukunan. } \\
\text { - } \\
\text { Anak tunarungu melakukan proses disasosiatif, yaitu } \\
\text { hubungan negatif yang terjalin saat interaksi terjadi. } \\
\text { Seperti pertengkaran, dan permusuhan. }\end{array}$ \\
\hline & & Hambatan & - Hambatan dalam berinteraksi dengan subjek lainnya. \\
\hline \multirow[t]{2}{*}{2.} & \multirow[t]{2}{*}{ Guru Kelas } & Komunikasi & $\begin{array}{l}\text { - Penggunaan bahasa komunikasi guru kepada anak } \\
\text { tunarungu. }\end{array}$ \\
\hline & & Proses Interaksi & - Upaya guru dalam memberikan pembelajaran kepada \\
\hline
\end{tabular}




\begin{tabular}{|c|c|c|c|}
\hline & & Sosial & anaktunarungu. \\
\hline & & Hambatan & $\begin{array}{l}\text { - Hambatan guru dalam menyampaikan pembelajaran } \\
\text { kepada anak tunarungu. } \\
\text { - Hambatan hubungan sosial guru dengan anak } \\
\text { tunarungu. }\end{array}$ \\
\hline 3. & $\begin{array}{l}\text { Guru } \\
\text { Pendamping }\end{array}$ & Komunikasi & $\begin{array}{l}\text { - Penggunaan bahasa komunikasi guru pendamping } \\
\text { kelas kepada anak tunarungu. }\end{array}$ \\
\hline & Kelas & $\begin{array}{l}\text { Proses Interaksi } \\
\text { Sosial }\end{array}$ & $\begin{array}{l}\text { - Upaya pendekatan guru pendamping kelas dengan } \\
\text { anak tunarungu. }\end{array}$ \\
\hline & & Hambatan & $\begin{array}{l}\text { Hambatan guru pendamping kelas dalam } \\
\text { berhubungan sosial dengan anak tunarungu. }\end{array}$ \\
\hline 4. & $\begin{array}{l}\text { Anak } \\
\text { Normal }\end{array}$ & Komunikasi & $\begin{array}{l}\text { - Penggunaan bahasa komunikasi anak normal dengan } \\
\text { anak tunarungu. }\end{array}$ \\
\hline & & $\begin{array}{l}\text { Proses Interaksi } \\
\text { Sosial }\end{array}$ & $\begin{array}{l}\text { - Perilaku anak normal saat bermain bersama anak } \\
\text { tunarungu. }\end{array}$ \\
\hline & & Hambatan & $\begin{array}{l}\text { - Hambatan anak normal dalam berhubungan sosial } \\
\text { dengan anak tunarungu. }\end{array}$ \\
\hline
\end{tabular}

2. Pedoman wawancara perlu disusun yang bertujuan agar fokus penelitian tidak menyimpang. Pedoman wawancara dibuat adalah untuk anak normal, guru kelas, dan guru pendamping kelas. Tujuan dari penggunaan pedoman wawancara adalah sebagai berikut.

a. Pedoman wawancara untuk anak normal bertujuan untuk mengungkapkan pendapat mereka tentang anak tunarungu, dan cara berinteraksi sosial mereka. Berikut adalah kisi kisi pedoman wawancara untuk anak normal.

Tabel 2. Kisi-Kisi Pedoman Wawancara untuk Anak Normal

\begin{tabular}{|l|l|l|}
\hline No. & \multicolumn{1}{|c|}{ Komponen } & \multicolumn{1}{c|}{ Indikator } \\
\hline 1. & $\begin{array}{l}\text { Kemauan Anak Normal } \\
\text { Berinteraksi dengan Anak } \\
\text { Tunarungu }\end{array}$ & $\begin{array}{l}\text { - Cara anak normal berkomunikasi dengan anak } \\
\text { tunarungu. } \\
\text { - Pengalaman anak normal melakukan kegiatan bersama } \\
\text { anak tunarungu }\end{array}$ \\
\hline 2. & $\begin{array}{l}\text { Sikap Anak Normal Terhadap } \\
\text { Anak Tunarungu }\end{array}$ & $\begin{array}{l}\text { - Sikap anak normal terhadap anak tunarungu. } \\
\text { - Tindakan negatif yang pernah diterima dari anak } \\
\text { tunarungu. }\end{array}$ \\
\hline
\end{tabular}

b. Pedoman wawancara untuk guru kelas bertujuan untuk mengetahui proses interaksi anak tunarungu dan upaya guru kelas dalam meningkatkan interaksi sosial anak tunarungu. Berikut adalah kisi - kisi pedoman wawancara untuk guru kelas.

Tabel 3. Kisi-Kisi Pedoman Wawancara untuk Guru Kelas

\begin{tabular}{|l|l|l|}
\hline No. & \multicolumn{1}{|c|}{ Komponen } & \multicolumn{1}{c|}{ Indikator } \\
\hline 1. & Proses Interaksi Tunarungu di & - Kontak sosial dan komunikasi anak tunarungu di kelas. \\
& dalam Kelas & - Guru kelas berkomunikasi dengan anak tunarungu. \\
& & - Kelebihan anak tunarungu dalam hal interaksi sosial. \\
& & - Perilaku negatif yang pernah dilakukan anak tunarungu. \\
& & - Sikap anak normal terhadap anak tunarungu. \\
& & - Kelemahan anak tunarungu dalam interaksi sosial. \\
\hline 2. & $\begin{array}{l}\text { Upaya Guru Kelas dalam } \\
\text { Meningkatkan Interaksi Sosial } \\
\text { Anak Tunarungu }\end{array}$ & $\begin{array}{l}\text { - Upaya guru kelas untuk meningkatkan kemampuan } \\
\text { interaksi sosial anak tunarungu. }\end{array}$ \\
& & - Sikap anak tunarungu ketika guru kelas memberikan \\
& & tugas kelompok. \\
& & Upaya guru kelas memberikan pembelajaran pada anak \\
& & tunarungu. \\
\hline
\end{tabular}


c. Pedoman wawancara untuk guru pendamping kelas bertujuan untuk mengetahui proses interaksi anak tunarungu dan upaya guru pendamping kelas dalam meningkatkan interaksi sosial anak tunarungu. Berikut adalah kisi - kisi pedoman wawancara untuk guru pendamping kelas.

Tabel 4. Kisi-Kisi Pedoman Wawancara untuk Guru Pendamping Kelas

\begin{tabular}{|l|l|l|}
\hline No. & \multicolumn{1}{|c|}{ Komponen } & \multicolumn{1}{c|}{ Indikator } \\
\hline 1. & Proses Interaksi Tunarungu di & - Kontak sosial dan komunikasi anak tunarungu di \\
& dalam Kelas & kelas. \\
& & - Guru pendamping kelas berkomunikasi dengan anak \\
& & tunarungu. \\
& & - Kelebihan anak tunarungu dalam hal interaksi sosial. \\
& & - Perilaku negatif yang pernah dilakukan anak \\
& & tunarungu. \\
& & - Sikap anak normal terhadap anak tunarungu. \\
& & - Kelemahan anak tunarungu dalam interaksi sosial. \\
\hline 2. & Upaya Guru Kelas dalam & - Upaya guru pendamping kelas untuk meningkatkan \\
& Meningkatkan Interaksi Sosial & kemampuan interaksi sosial anak tunarungu. \\
& Anak Tunarungu & \\
\hline
\end{tabular}

\section{Hasil Dan Pembahasan}

\section{Bentuk Perilaku Anak Tunarungu}

Pi saat di kelas lebih cenderung menyendiri dan hanya melihat temannya saja. Emosinyapun tidak stabil apalagi saat dia merasa tersakiti dan tidak nyaman dengan lingkungan disekitarnya. Hal tersebut relevan dengan pernyataan Mufti \& Soemargo (1984) yang menyatakan bahwa anak tunarungu mampu melihat kejadian yang terjadi di sekitarnya, namun dia tidak mampu mengikuti dan memahami kondisi tersebut sehingga dapat menimbulkan perkembangan emosi yang tidak stabil, perasaan curiga, dan kurang percaya diri. Pekembangan emosi pada anak tunarungu lebih tidak stabil dari anak normal pada umumnya. Berbeda dengan hasil penelitian yang dilakukan oleh Margaretha Langen Sekar Lelyana dalam penelitiannya menunjukkan ketiga responden anak tunarungu memiliki kepribadian yang ceria, dapat bergaul dengan orang lain dengan baik, dan memiliki emosi yang baik (Margaretha L.S. Lelyana, 2017). Dalam penelitian yang dilakukan oleh Margaretha dilaksanakan di Sekolah Dasar Luar Biasa dengan menunjukkan perilaku anak tunarungu saat berada di sekolah maupun di rumah.

Namun, Pi merupakan anak yang mandiri dan memiliki jiwa sosial yang tinggi untuk mengapresiasi hasil kerja temannya yang lebih bagus dari hasil kerjanya. Kejadian tersebut berbanding terbalik dengan pernyataan Edja \& Darjo (1995) yang mengatakan karakteristik kepribadian anak tunarungu adalah memiliki sifat ketergantungan pada orang lain atau kurang mandiri di dalam bukunya. Pada kenyataannya Pi sebagai anak berkebutuhan khusus dapat mandiri dan bisa di tinggal oleh orang tua serta tidak meminta di temani oleh gurunya setiap saat. Pi juga mampu mengerjakan pekerjaan sendiri, walaupun saat dia tidak mengerti dengan pembelajaran yang disampaikan oleh guru dia akan bertanya pada temannya atau guru. Teori tersebut juga berbanding balik dengan penelitian yang dilakukan oleh Margaretha, dalam penelitiannya ketiga responden anak tunarungu menunjukkan kemampuan yang baik terhadap teman sesama tunarungu, maupun dengan teman-teman yang lainnya (Margaretha L.S. Lelyana, 2017). Bentuk perilaku anak tunarungu tersebut seperti berbagi makanan dengan teman lainnya, merangkul pundak temannya saat berjalan, dan menghampiri temannya yang memanggil.

Jadi dapat disimpulkan bahwa kekurangan dalam hal mendengarkan dan mengganggu perkembangan bahasa dan bicaranya dapat juga mempengaruhi perkembangan emosinya. Anak

Child Education Journal. Volume 1, No. 2 December 2019, 78-87 
tunarungu akan cenderung menyendiri dan hanya mengawasi teman-temannya, namun tidak menutup kemungkinan terdapat beberapa anak tunarungu yang dapat berinteraksi dengan baik dengan lingkungan disekitarnya. Namun, kelebihan yang dimiliki oleh Pi adalah dia merupakan anak berkebutuhan khusus yang mandiri. Dalam mengerjakan tugasnya Pi dapat melakukannya sendiri dan dapat di tinggal oleh orang tua serta guru. Pada umumnya anak berkebutuhan khusus akan bergantung pada orang lain dan tidak mandiri.

\section{Interaksi Sosial Anak Tunarungu}

a. Interaksi Sosial Anak Tunarungu dengan Guru Kelas

Interaksi sosial yang terjadi antara anak tunarungu dengan guru kelasnya berjalan dengan baik. Hal tersebut di tunjukkan dengan anak tunarungu yang selalu bertanya pada gurunya saat dia tidak mengerti dan tidak tahu tentang hasil kerjanya. Menurut H. Bonner interaksi sosial merupakan hubungan antara dua individu atau lebih, yang mana setiap perilaku satu individu di antaranya dapat mempengaruhi, mengubah, dan memperbaki perilaku individu yang lainnya (Ahmadi Abu, 2002).

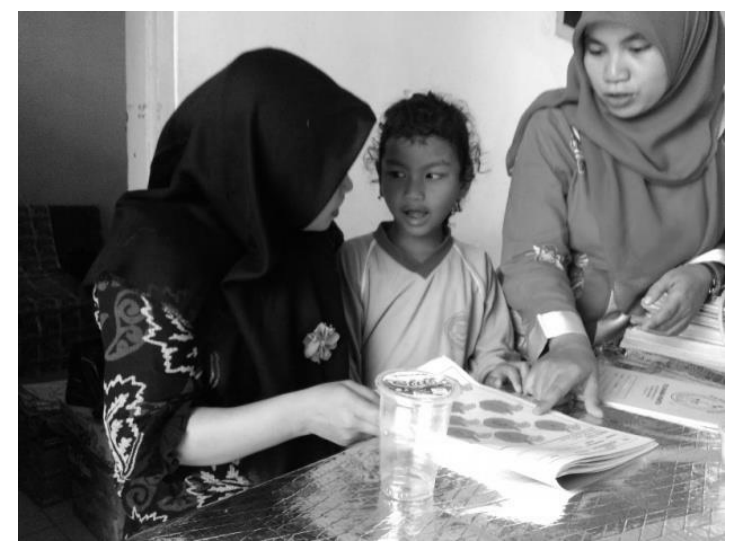

Gambar 1. Anak tunarungu bertanya kepada guru kelas dan guru pendamping kelas

Namun, yang menjadi kendala adalah cara anak tunarungu untuk berkomunikasi yang tekadang sulit untuk dipahami oleh guru kelasnya. Hal tersebut sejalan dengan karakteristik pada aspek bahasa-bicara anak tunarungu yang dikemukakan oleh Edja (2005) bahwa anak tunarungu sulit menggunakan struktur kalimat. Hal tersebut dikarenakan ketidakmampuan anak tunarungu dalam mendengarkan dan menirukan suara, sehingga mempersempit berbendaharaan kata yang di terimanya.

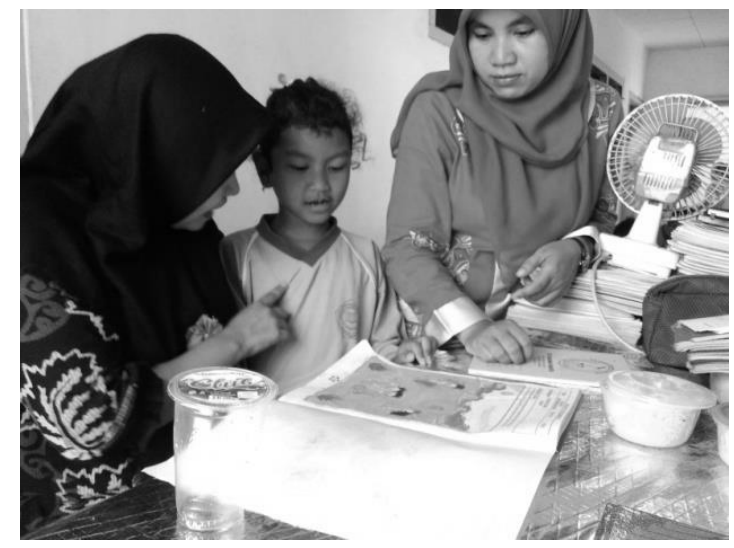

Gambar 2. Anak tunarungu berkomunikasi dengan guru kelas dan guru pendamping kelas 
Dapat disimpulkan bahwa interaksi yang terjadi antara guru kelas dengan anak tunarungu berjalan cukup baik dengan ditunjukkan anak tunarungu yang bertanya pada guru kelas tentang sesuatu hal yang tidak di mengerti. Dalam berinteraksinya tersebut guru kelas memiliki kendala dalam memahami perkataan anak tunarungu. Hal tersebut dikarenakan anak tunarungu sulit dalam menggunakan struktur kalimat dan hanya bisa membuka mulutnya yang bersuara "ah ah" saja. Interaksi yang dilakukan Pi dengan guru kelas masih sangat baik dibandingkan dengan penelitian yang dilakukan oleh Mura Restu Syaputra di SDN Gerantung Praya Tengah yang menunjukkan hasil bahwa warga sekolah, yang meliputi kepala sekolah, guru, dan wali murid menunjukkan kurangnya kesadaran atas adanya anak tunarungu dalam sekolah mereka (Mura Restu Syaputra, 2014). Dalam penelitiannya tersebut menunjukkan kurangnya perhatian guru dan metode pembelajaran yang kurang mendukung bagi anak tunarungu.

b. Interaksi Sosial Anak Tunarungu dengan Guru Pendamping Kelas

Interaksi yang terjadi antara guru pendamping kelas dengan anak tunarungu sama halnya dengan interaksi sosial yang terjadi dengan guru kelas dan anak tunarungu. Saat Pi tidak mengerti tentang pembelajarannya dia akan menanyakannya pada guru pendamping kelas. Interaksi yang terbentuk antara guru pendamping kelas dan anak tunarungu sudah sangat rekat. Hal ini berbanding terbalik terhadap karakteristik kepribadian anak tunarungu yang di kemukakan oleh Edja \& Darjo (1995) bahwa anak tunarungu memiliki perasaan takut apabila hidup di lingkungan yang lebih besar daripada lingkungan keluarganya sendiri. Apabila anak tunarungu takut untuk hidup di lingkungan yang lebih besar, maka Pi tidak akan mau berangkat ke sekolah setiap harinya. Namun, Pi masih semngat pergi ke sekolah.

Saat Pi mendapatkan masalah dia juga mengadu pada guru pendamping kelasnya. Hal tersebut sejalan dengan kerakteristik kepribadian anak tunarungu yang dikemukakan oleh Edja \& Darjo (1995) yang menyatakan bahwa anak tunarungu memiliki perasaan yang cepat marah dan mudah tersinggung. Sehingga di sini guru pendamping kelas mengambil peran untuk bersikap bijaksana untuk menyelesaikan masalah yang dihadapi antara anak tunarungu dengan anak normal. Teori tersebut berbanding terbalik juga dengan penelitian yang dilakukan oleh Luluk Khotimah yang dilaksanakan di TK Alvenver yang menunjukkan bahwa kedua respondennya memperlihatkan interaksi yang baik dengan guru pendampinya (Luluk Khotimah, 2019). Dalam penelitiannya menunjukkan bahwa anak tunarungu menanyakan sesuatu hal yang tidak mengerti kepada guru pendamping, sehingga anak tunarungu tidak mengalami kebingungan terhadap pembelajaran.

Dapat disimpulkan bahwa interaksi sosial anak tunarungu dengan guru pendamping kelas berjalan dengan baik dengan ditunjukkan apabila Pi tidak memahami pembelajaran maka dia akan bertanya pada guru pendamping kelas. Interaksi sosial tersebut di tunjukkan saat Pi mendapatkan masalah dengan anak normal lainnya, maka guru kelas membantu menyelesaikan masalah yang ada di antara Pi dan anak normal. Perilaku sosial yang ditunjukkan Pi sebanding dengan penelitian yang dilakukan oleh Luluk Khotimah yang menunjukkan hasil bahwa kedua responden anak tunarungu juga menunjukkan perilaku yang sama apabila mengalami kesulitan dalam memahami pembelajaran di kelas.

c. Interaksi Sosial Anak Tunarungu dengan Anak Normal

Selama Pi belajar di TK Syafina dia tidak pernah memilih-milih teman dan tidak hanya tergantung pada anak tertentu. Kejadian tersebut berbanding terbalik dengan pernyataan Edja \& Darjo (1995) tentang karakteristik kepribadian anak tunarungu yang hanya lebih dekat dengan orang yang di kenalnya saja. Pi termasuk anak tunarungu yang tidak memilih dalam berteman. Walaupun emosi Pi tidak stabil namun selama Pi sekolah, dia tidak pernah menyakiti dan memukul teman-temannya. Sikap Pi hampir sama dengan hasil penelitian yang dilakukan oleh

Child Education Journal. Volume 1, No. 2 December 2019, 78-87 
Luluk Khotimah yang dilaksanakan di TK Alvenver terhadap dua responden anak tunarungu (Luluk Khotimah, 2019). Responden pertama memiliki interaksi yang sama dengan Pi dengan menunjukkan sikap yang baik, tidak memilih-milih teman, dan berkomunikasi dengan temannya menggunakan mimik muka, gestur tubuh, dan dengan menggerakkan mulutnya. Pada responden kedua dalam penelitian Luluk Khotimah lebih terlihat memilih-milih teman dikarenakan banyak teman lainnya kurang memahami Bahasa yang disampaikan oleh responden kedua, dan juga emosi responden kedua lebih suka marah-marah sehingga teman yang mau berinteraksi dengan dia hanya sedikit.

Pi dapat bekerja sama dengan teman-teman lainnya, walaupun cara berkomunikasi Pi menghambat pemahaman anak normal dalam bermain. Hal tersebut berbanding terbalik dengan pernyataan Edja \& Darjo (1995) yang menyatakan salah satu karakteristik kepribadian anak tunarungu adalah kurang memiliki konsep tentang menjalin sebuah hubungan. Pada Pi dia dapat bekerjasama dengan anak normal dengan membagi crayonnya kepada anak normal yang tidak membawanya.

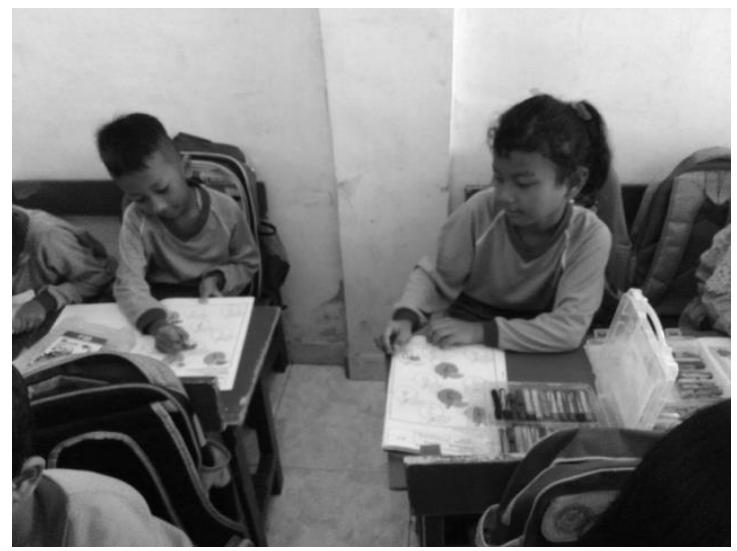

Gambar 3. Anak tunarungu berbagi crayon dengan anak normal

Dapat disimpulkan bahwa interaksi sosial yang terjadi pada anak tunarungu dengan anak normal terjalin baik dengan adanya kerja sama yang terbentuk antara Pi dengan anak normal lainnya. Hal tersebut ditunjukkan dengan Pi sering membagi crayonnya kepada anak normal yang tidak membawa crayon. Pi juga tidak memilih - milih teman, dan tidak pernah menyakiti ataupun memukul teman - temannya. Sikap yang ditunjukkan oleh Pi juga sebanding dengan hasil penelitian yang dilakukan oleh Luluk Khotimah terhadap anak tunarungu yang memiliki karakteristik dan kemampuan seperti Pi yang memiliki interaksi social yang baik dengan teman normal lainnya.

\section{Kesimpulan}

Berdasarkan hasil penelitian dan pembahasan di atas, maka dapat disimpulkan sebagai berikut. Pertama, bentuk perilaku anak tunarungu di sekolah umum cenderung menyendiri dan hanya mengawasi teman - temannya dari jauh. Hal tersebut membuat Pi cepat marah dan mudah tersinggung karena dia merasa tidak mampu menjadi seperti teman - temannya. Namun, kelebihan yang dimiliki oleh Pi adalah dia merupakan anak berkebutuhan khusus yang mandiri. Dalam mengerjakan tugasnya Pi dapat melakukannya sendiri dan dapat di tinggal oleh orang tua serta guru. Pada umumnya anak berkebutuhan khusus akan bergantung pada orang lain dan tidak mandiri.

Kedua, interaksi sosial anak tunarungu dengan guru kelas berjalan baik dengan ditunjukkan anak tunarungu yang bertanya pada guru kelas tentang sesuatu hal yang tidak di 
mengerti. Dalam berinteraksinya tersebut guru kelas memiliki kendala dalam memahami perkataan anak tunarungu. Hal tersebut dikarenakan anak tunarungu sulit dalam menggunakan struktur kalimat dan hanya bisa membuka mulutnya yang bersuara "ah ah" saja. Interaksi sosial anak tunarungu dengan guru pendamping kelas berjalan dengan baik dengan ditunjukkan apabila Pi tidak memahami pembelajaran maka dia akan bertanya pada guru pendamping kelas. Interaksi sosial tersebut di tunjukkan saat Pi mendapatkan masalah dengan anak normal lainnya, maka guru kelas membantu menyelesaikan masalah yang ada di antara Pi dan anak normal. Interaksi sosial yang terjadi pada anak tunarungu dengan anak normal terjalin baik dengan adanya kerja sama yang terbentuk antara Pi dengan anak normal lainnya. Hal tersebut ditunjukkan dengan Pi sering membagi crayonnya kepada anak normal yang tidak membawa crayon. Pi juga tidak memilih - milih teman, dan tidak pernah menyakiti ataupun memukul teman - temannya.

Saran yang dapat dikemukakan penulis untuk sekolah agar menjadi lebih baik sebagai berikut: 1) sebaiknya TK Syafina Surabaya menyediakan Guru Pendamping Khusus (GPK) untuk anak tunarungu agar pembelajaran yang disampaikan bisa efektif untuk $\mathrm{Pi}, 2$ ) hendaknya keluarga dan sekolah bekerjasama mengajarkan dan membiasakan bahasa isyarat sebagai alat komunikasi Pi dalam berinteraksi sosial dengan lingkungan di sekitarnya, 3) guru kelas atau guru pendamping kelas hendaknya lebih mengelolah tata ruang agar lebih membaur kepada Pi dan Pi merasa nyaman berada di sekitar anak normal.

\section{Daftar Pustaka}

Abu, A. (2002). Psikologi Sosial. Jakarta: PT. Rineka Cipta.

Alimin, Z. (2016). Anak Berkebutuhan Khusus. Modul 1. 1-12.

Edja, S. \& Dardjo, S. (1995). Bina Bicara, Persepsi Bunyi dan Irama. Bandung: Depdikbud.

Edja, S. (2005). Pendidikan Bahasa Bagi Anak Gangguan Pendengaran dalam Keluarga. Jakarta: Depdiknas.

Fitriyah, Fifi Khoirul. (2019). Pengaruh Permainan Tradisional Gobak Sodor dalam Bimbingan Kelompok terhadap Peningkatan Interaksi Sosial Anak Autis. Education and Human Development Journal, 5(1), 13-20. https://doi.org/10.33086/ehdj.v5i1.1293

Ilahi, M. T. (2013). Pendidikan Inklusif: Konsep dan Aplikasi. Jogjakarta: Ar-Ruzz Media.

Khotimah, Luluk. (2019). Interaksi Sosial Anak Tunarungu di Sekolah Study Kasus di TK Alvenver Surabaya. Skripsi. UIN Sunan Ampel Surabaya.

Lelyana, Margaretha L. S. (2017). Interaksi Sosial Anak Tunarungu dan Anak Tunarungu dengan “Anak Dengar”. Skripsi. Universitas Sanata Dharma Yogyakarta.

Moeleong, J Lexy. (2007). Metode Penelitian Kualitatif. Bandung: PT. Remaja Rosdakarya.

Mufti, S. \& Soemargo, S. (1984). Pendidikan Anak Tunarungu. Jakarta: Depdikbud.

Sardjono. (2005). Terapi Wicara. Jakarta: Depdiknas.

Sugiyono. (2009). Metodologi Penelitian Kuantitatif, Kualitatif dan R\&D. Bandung: Alfabeta.

Sutjihati, S. (2006). Psikologi Anak Luar Biasa. Bandung: Refika Aditama.

Syaputra, Mura S. (2014). Persepsi Warga Sekolah Terhadap Interaksi Sosial Siswa Tunarungu di SDN Gerantung Praya Tengah. Jurnal Pendidikan Khusus. 